\title{
血小板凝集起因脳血管傷害発生機序の電顕的解析
}

\author{
藤本 司* 鈴木 英紀 ${ }^{* *}$ 小林 正彦*** \\ 田上憲次郎** 福島 義治* 山崎 博男**
}

\section{Electron microscopic analysis of the process of cerebrovascular injury caused by platelet aggregation}

\author{
Tsukasa FUJIMOTO*, Hidenori SUZUKI**, Masahiko KOBAYASHI***, \\ Kenjiro TANOUE**, Yoshiharu FUKUSHIMA* and Hiroh YAMAZAKI**
}

Key words: ADP, cerebrovascular injury, vesicular transport, horseradish peroxidase (HRP), electron microscope

When platelets were aggregated with an injection of ADP into cerebral artery, cerebrovascular injuries were observed. For analysis of the process of this vascular injury, electron microscopic observation was performed using horseradish peroxidase (HRP) as a marker of vascular permeability change. Two different types of changes; increased vesicular transport and vacuole formation were recognized. Vesicules $(0.05-0.2 \mu \mathrm{m})$ contained HRP reaction product but vacuoles $(1.2-2.0$ $\mu \mathrm{m})$ did not. In middle cerebral artery, vacuole formation was mainly revealed. Extravasation of HRP reaction products was not seen. In capillaries, arterioles or venules, increased vesicular formation was rare. Extravasation and perivascular edematous changes were remarkable. Namely endothelial cell damage was more prominent in large artery but extravasation and perivascular edematous changes were mainly seen in smaller vessels. And extravasation was more frequently seen in cerebral cortex and hippocampus comparing with basal ganglia. Following the ADP injection, blood levels of $\mathrm{TXB}_{2}$ and 6-keto $\mathrm{PGF}_{1 \alpha}$ revealed marked temporarily increase at $3 \mathrm{~min}$ after the injection. The results suggest that these vasoactive substances from platelets may play an important role in producing

* 昭和大学藤が丘病院脳神経外科〔テ227 横浜市緑区藤が丘 1-30], Department of Neurosurgery, Showa University, Fujigaoka Hospital, Yokohama, Japan.

** 東京都臨床医学総合研究所循環器部, Department of Cardiovascular Research, Tokyo, Metropolitan Institute of Medical Science, Tokyo, Japan.

*** 日本動脈硬化研究所, Japan Arteriosclerosis Research Institute, Tpkyo, Japan.〔1984年6月 9 日受付, 1984 年 8 月20日受理] 
these vascular injuries.

These phenomenon seems to be important to understand the mechanism of vascular damage in various cerebrovascular lesions.

\section{はじめに}

生体内に执いて血管内血小板を活性化するこ とにより，正常の脳血管に傷害が発生すること を報告してきだ2). 本研究はさらにその詳細 を明らかにするため，血小板凝集起因物質であ る $\mathrm{ADP}$ を内頸動脈内に投与し，脳血管に生ず る傷害の発生機序を脳組織の部位，ならびに太 さによる傷害像の差の上から検討した。また血 小板の活性化に伴い，生物学的活性の高い物 質，すなわちセロトニン，プロスタグランディ ン中間体やトロンボキサン $\mathrm{A}_{2}\left(\mathrm{TXA}_{2}\right)$ 等が放 出されるため, これらの物質が血管傷害発生に 関係している可能性が考兄られる.そこで ADP 注入後, 同側内頸静脈血の $\mathrm{TXB}_{2}\left(\mathrm{TXA}_{2}\right.$ の終 末代謝産物), 巧よび 6-keto $\mathrm{PGF}_{1^{\alpha}}\left(\mathrm{PGI}_{2}\right.$ の 終末代謝産物）の血中濃度を経時的に測定し， 血管傷害との関係を検討した.

\section{I. 方 法}

白色家鬼13羽を用い，全麻下でポリエチレン チューブを右外頸動脈から逆行性に頸動脈分岐 部まで挿入し，内頸動脈の血流を妨げずに 40 $\mathrm{mg} / \mathrm{kg}$ (濃度 $60 \mathrm{mg} / \mathrm{ml}$ ) の ADP を 60 秒間で 注入し， 5，15，60 分後に屠殺した。な扮屠殺 15 分前に $25 \mathrm{mg} / \mathrm{kg}$ の horseradish peroxidase (HRP) を, 屠殺 30 分前に $2 \%$ ェバンス・ブル 一を静注し血管透過性障害の指標とした，脳を 摘出後, クモ膜下腔内を走行する中大脳動脈の ほか，脳組織の各所，すなわち大脳皮質，海馬， 大脳基底核の小片を切り出し， $2.5 \%$ グルター ルアルデヒド液で固定後型の如く電顕標本を作 成し，JEM-100S (JEOL) を用いて観察した。 また脳の相対する半分から凍結切片を作成し， ジアミノベンチジン処理にて HRP 反応物質の 分布を光顕的に観察した。 一方 9 羽を用い同様 に頸動脈, さらに右内頸静脈にポリエチレンチ ューブを挿入し，上記と等量の ADP を同じ条
件で注入した. 注入前, 3,60 分後に静脈血を 採取し，RIA 法にて $\mathrm{TXB}_{2}, 6$-keto $\mathrm{PGF}_{1^{\alpha}}$ の 血中濃度を測定した ${ }^{3) 4)}$.

\section{II. 結 果}

$\mathrm{ADP}$ 注入 60 分後, 注入側にのみエバンス・ ブルーによる青染がみられ，光顕的にこの領域 に一致して HRP 反応物質の血管外漏出がみら れた。血管外漏出は注入側の大脳皮質，海馬， ついで大脳基底核の順に高頻度でみられた，各 部位では特に毛細血管, 細動静脈の周团に強く みられた．一方中大脳動脈では HRP 反応物質 を血管腔内に認めたが，血管外漏出は明らかで はなかった．電顕的には，中大脳動脈では注入 5 分後, 注入側の血管腔内に脱顆粒がみられる 活性化された血小板がみられ，血管内皮細胞内 飞 HRP 反応陽性の vesicle（直径 $0.05 \sim 0.2$ $\mu \mathrm{m} ）$ が血管腔に面する内皮細胞表面近くで, 非注入側の約 $4 \sim 6$ 倍に増加して抒り, HRP 反応陰性の vacuole（直径 $1.0 \sim 2.0 \mu \mathrm{m}$ ) が時 にみられた. 15 分後では vacuole はさらに高 頻度にみられるが vesicle の増加は著明ではな かった. 60 分後には内皮細胞内に多数の vacuole がみられ, 細胞質の他の部分には HRP 反 応物質が充満していた。一部では内皮細胞の剝 離がみられ，その部には血小板凝集塊が認めら れた. 血管壁の蛇行, 内皮細胞下あるいは内弾 性板下の浮腫性変化は著明であったが, HRP 反応物質の血管外漏出はみられなかった，全経 過を通じて tight junctionはよく保たれてい た. 一方 ADP 注入側の脳実質内の毛細血管, 細動静脈では vacuole の出現は極めて少く, vesicleの増加が中心であった．時間の経過とと もに増加し，60 分後には HRP 反応物質の血管 外漏出, 血管周囲の浮腫性変化が著明にみられ た.しかしながら tight junction はこれらの細 い血管でもよく保たれていた．太い中大脳動脈 の場合と異なり，内皮細胞の剝離はみられなか 


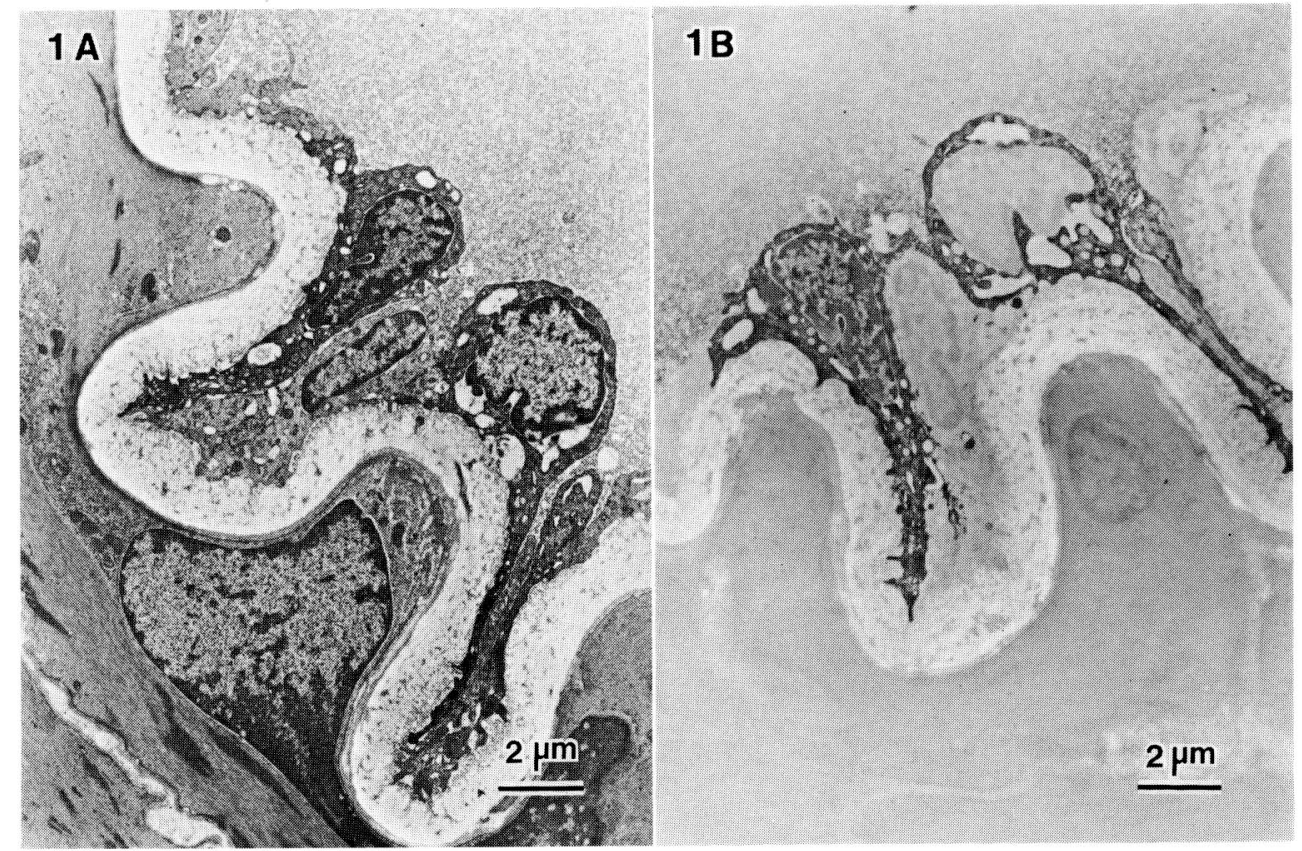

Fig. 1 Electron microscopic findings of middle cerebral artery sixty min after an injection of ADP. (1A) : Remarkable HRP negative vacuoles in the endothelial cells are seen. Tortuosity of internal elastic lamina and edematous changes in subendothelial tissue and muscle layers are also revealed.

(1B) : Unstained specimen. Many HRP negative vacuoles are observed in the endothelial cells. Although the cytoplasma was filled with black HRP reaction products, extravasation is not seen.

った。なお，非注入側では血管はよく保たれて おりこれらの変化はみられなかった。一方 $\mathrm{TXB}_{2}$ 血中濃度の注入前, 3,60 分後の平均值士 標準偏差は， $0.346 \pm 0.143 \mathrm{ng} / \mathrm{ml} ， 1.266 \pm$ $0.741 \mathrm{ng} / \mathrm{m} l, 0.460 \pm 0.294 \mathrm{ng} / \mathrm{m} l$ であった. 6-keto $\mathrm{PGF}_{1 \alpha}$ は各々, $0.833 \pm 0.403 \mathrm{ng} / \mathrm{m} l$, $5.427 \pm 1.521 \mathrm{ng} / \mathrm{ml}, \quad 1.342 \pm 0.707 \mathrm{ng} / \mathrm{ml}$ で あり, 3 分後に共に有意 $\left(\mathrm{TXB}_{2}\right.$ は $\mathrm{p}<0.02$, 6-keto $\mathrm{PGF}_{1 \alpha}$ は $\left.\mathrm{p}<0.001\right)$ な一過性の上昇が みられ，60分後には再び前值にもどっていた. 上昇の程度は 6-keto $\mathrm{PGF}_{1 \alpha}$ でより著明であっ た。

\section{III. 考察および結論}

$\mathrm{ADP}$ 注入後，血小板凝集に伴って出現する 血管内皮細胞傷害には，HRP 反応物質を含苔 ない vacuole の出現 $\zeta$, 含む vesicular transportの増強とがみられた，血管の太さによりそ の出現様式が異って拈り，細い血管，すなわち
毛細血管，細動静脈の内皮細胞では vesicular transport 穴進が主であり，その結果と考えられ る HRP 反応物質の血管外漏出，血管周囲の浮 腫性変化が著明にみられた，一方大型の動脈, すなわら中大脳動脈の内皮細胞では vacuole が 著明にみられた。 vacuole は HRP を含えでい ず, ミトコンドリアや RES の変化したもので ある可能性が考えられるが明らかではない，変 化が著明な内皮細胞では多数の vacuole が細胞 内に出現し， HRP 陽性物質が細胞質内一広沉 に侵入していた。一部では内皮細胞と内弾性板 との間にも vacuole が認められた。しかしなが ら血管外への HRP 陽性物質の漏出は認められ ず，細い血管の傷害像とは異っていた，本来， 血管壁をと扎しての物質交換は毛細血管で最も 盛んであり，この部での vesicular transport の 著増は極めて理解しやすい現象と思われる.こ 孔らの血管では，剥離にまで進むような内皮細 胞の傷害はみられず，透過性六進との関係で大 


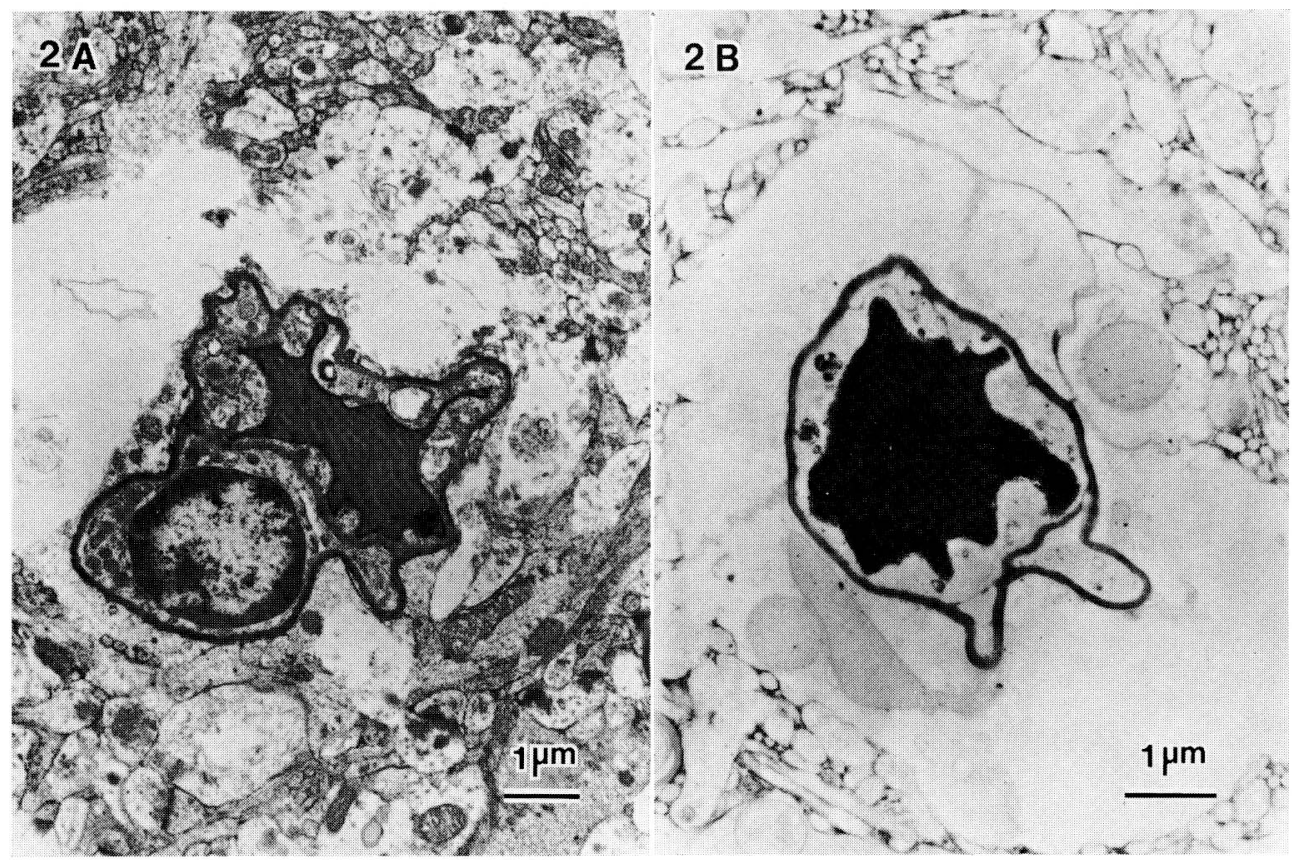

Fig. 2 Capillary in cortex sixty min after the injection.

(2A): Various-sized vesicles containing reaction products are increased in endothelial cells but HRP negative vacuoles are rarely seen. Prominent perivascular edematous changes are revealed.

(2B): Unstained specimen. Black HRP positive vesicles in endothelial cells and prominent extravasation of HRP reactive products are clearly seen.

変興味深いことと思われた．太い血管で内皮細 胞豩離にまで進みうる細胞自身の傷害が強く生 じたが，この原因としては透過性の元進という ことよりも，血管攣縮の発生，厚い内弾性板の 存在等がより関係している可能性が考光られ る. 脳の部位別では大脳皮質, 海馬, 大脳基底 核の順に血管外漏出がより高頻度にみられた。 しかしながら部位間の血管傷害像には明らかな 差を見い出し得なかった。これらの部位は大脳 血管皮質枝，西るいは穿通枝に支配されて拈 り，血行動態を含めた種々の要因が発現頻度の 差に関係していると考党られる. ADP 注入の 際のこれらの血管傷害の原因として，血小板凝 集塊による微小循環障害の可能性を考学なけれ ばならないが，ADP による凝集は一過性であ り, 注入直後には多数凝集塊を認めても5 分後 にはわずかに散在しているのを認めるにすぎな い、したがってこれによる虚血を主な原因と考 えることはできない，一方 ADP 注入後の TX
$\mathrm{B}_{2}$ ，6-keto $\mathrm{PGF}_{1 \alpha}$ の血中濃度の経時的変化を みると, 共に 3 分後に一過性の著増がみられた。 $\mathrm{TXA}_{2}$ は血小板から遊離される生物学的活性物 質の中でも極めて強力な血管作動物質であり ${ }^{5)}$, $\mathrm{ADP}$ 注入後の $\mathrm{TXB}_{2}$ の著明な増加は, $\mathrm{TXA}_{2}$ がここに観察しえた血管傷害の原因の一つとな っている可能性をしめしていると思われる. $\mathrm{PGI}_{2}$ は逆に血小板凝集を抑制 乙，血管壁の防 禦機能を持って和り ${ }^{6)}$ ， TXA ${ }_{2}$ の增加とともに それ以上の著明な増加を示したことは，生体の 防禦機構を考学るとさ極めて興味深いことであ る.

脳血管の太さ，部位により異った傷害像が棸 られるということは, 脳血管傷害の成因解明に あたり重要であると考える。

\section{文献}

1) Fujimoto T., Inaba $Y$., Motomiya T. and Yamazaki $\mathrm{H}$ : Intravascular aggregation of 
platelets and cerebrovascular insufficiency. In Circulatory and Developmental Aspects of Brain Metabolism. Ed. Spatz M. et al. Plenum Press, New York and London, 1980, p. 169 $\sim 180$.

2) Yamazaki H., Motomiya T. and Fujimoto T. : Vascular injuries induced by intravascular platelet aggregation. Acta Haematol. Jpn., 43 (6) ; 208 216, 1980.

3) Yamazaki, H., Isohisa, I. and Tanoue, K. : Sudden death induced by intracoronaly platelet aggregation. Jpn. Circ. J., 47 (5) ; 596 607, 1983.
4) Wuthier R.E. : Purification of lipids from nonlipid contaminants on sephadex beads columns. J. Lipid Res., 7; 558 561, 1966.

5) Hamberg M., Svensson J. and Samuelsson B : Thromboxanes, a new group of biologically active compounds derived from prostagrandin endoperoxides. Proc. Natl. Acad. Sci. U.S.A., 72; 2994 2998, 1975.

6) Moncada, S., Gryglewski, R., Bunting, S. and Vane, J.R. : An enzyme isolated from arteries transform prostaglandin endoperoxide to an unstable substance that inhibits platelet aggregation. Nature, 263; 663 665, 1976.

\section{○治療指針亡問題点を解説する! 急性白血病の化学療法一基砋々臨休-} 編集 京都大学内科教授 内野治人ほか 専門医33氏分担執筆 A 5 判 268頁図106 表65 定価6,800円(干300円)

最近の急性白血病化学療法の進歩は著しいものがあり, 新しい薬剤の開発と作用機序の解明, 量, 種類, 使い方など, 臨床のための数々の基礎的研究が全世界的にわたって集積された。本 書はそれらの研究を整理して，ルーチン化できるものは治療指針として設立し，しかも現在の 問題点を浮き彫りにして解説し，今後の研究に資した。

○内容：〔急性白血病化学療法の基碟〕第 1 章 白血病細胞の分化と化学療法, 第 2 章 抗白血病剤の作用 機序と臨床効果, 第 3 章 造血器腫瘍細胞培養株の薬剤感受性度, 第 4 章 細胞回転と化学療法, 第 5 章 急性白血病における新しい治療法の試み, 第 6 章 染色体分析からみた急性非リンパ性白血病化学療法の二, 三の問題点, 〔急性白血病化学療法の臨床〕第 1 章 成人急性白血病の化学療法, 第 2 章 小児の急性リン 八性白血病の治療, 第 3 章 血球成分の輸血療法, 第 4 章 出血症状とその治療, 第 5 章 感染症の治療, 第 6 章 無菌病室による急性白血病治療, 第 7 章 無菌室治療における腸管内無菌化処置, 第 8 章 白血病 の顆粒球機能異常と感染症化学療法, 総括。 